\title{
INFLUENCE OF ADDITION SPIRULINA PLATENSIS ALGAE POWDER ON REPRODUCTIVE AND PRODUCTIVE PERFORMANCE OF DAIRY ZARAIBI GOATS
}

\author{
E.I. Khalifa ${ }^{1}$, Hanan A.M. Hassanien' ${ }^{2}$ A.H. Mohamed $^{2}$, A.M. Hussein ${ }^{2}$ and Azza A.M. \\ Abd-Elaal ${ }^{2}$ \\ ${ }^{1}$ Animal Production Research Institute, Sheep and Goats Research Department, Dokki, Giza, Egypt. \\ ${ }^{2}$ Animal Production Research Institute, By-Products Research Department, Dokki, Giza, Egypt. \\ Corresponding author: xyezz@yahoo.com
}

(Received 28/3/2016, Accepted 1/6/2016)

\section{SUMMARY}

$\mathrm{T}$

The current work studied the addition of Spirulina platensis powder (SPP) to dairy nanny goat rations on the reproductive and productive performance. Fourteen dairy Zaraibi goats with an average body weight of $36.00 \mathrm{~kg}$ at 33.43 months of age were used in this study. The Zaraibi nanny goats were distributed randomly in two groups ( $\mathrm{n}=7$ in each). The first group control (G1) was fed concentrate feed mixture (CFM) plus roughage as Egyptian berseem hay $(\mathrm{BH})$ and rice straws (RS) plus orally empty rice paper sack / head /day. While, the second group (G2) was serviced as trial group and nourished previous control ration plus $500 \mathrm{mg}$ of SPP stuffed into rice paper sack given orally/ head / day. Experimental diet was offered to either G1 or G2 twenty-one days pre-breeding season till postnatal to study reproductive performance. After postnatal, similarly eight does in parity rate $(\mathrm{n}=4$ in each) were selected from later $\mathrm{G} 1$ and G2 and continued to fed last rations to study changing in udder measurements, suckling milk amount, variable in body weight of does and their kids, milk yield and blood metabolites. The results indicated that litter size and the quaternary rate were lower values in G1 than G2. Moreover, reproductive parameters in G2 have booster $(\mathrm{P}<0.05)$ udder formation than $\mathrm{G} 1$ during suckling months. The highest $(\mathrm{P}<0.05)$ values of suckling milk observed in $\mathrm{G} 2$ at all suckling months compared to G1. The highest $(\mathrm{P}<0.05)$ suckling milk energy obtained with G2 compared to G1 that may be attributed to difference $(\mathrm{P}<0.05)$ percentage values of fat and protein. The growth rate and daily weight gain of does in G2 and their kids achieved greater weight than does in G1 during suckling months. Based on early seven weeks (peak lactation curve) of milk yield, does in G2 showed significantly $(\mathrm{P}<0.05)$ higher milk yield through first three weeks, but the lactation curve during another four weeks declines almost similar trend $(\mathrm{P}>0.05)$ in milk yield compared to G1. Also, blood biochemical parameters e.g. total protein and glucose in $\mathrm{G} 2$ had significantly $(\mathrm{P}<0.05)$ higher than $\mathrm{G} 1$. However, G1 had greater $(\mathrm{P}<0.05)$ in cholesterol, triglycerides, AST and ALT concentration than those does in G2. Intriguingly, there was no significant difference in the concentrations of urea among goats in G1 and G2. Also, the present results revealed that lower feed cost of milk production was 1.45 L.E in G2 compared to G1 group (1.84 L.E). The present study clearly demonstrates that the SPP could be incorporated in diets as an increment of milking production and non-specific resistance of organism.

Keywords: Dairy Zaraibi goats, production and reproduction performance and powder of Spirulina platensis algae.

\section{INTRODUCTION}

Reproductive and productive traits of dairy goats are primary interest in terms of the economic efficiency of production systems and a process essential to the maintenance of a species. The survival of kids in extensive goats' production systems is a major contributing factor to the economic efficiency to the goats herd and is an indicator of good animal welfare. Starvation / exposure in the first week of newborn life occurred $60 \%$ of all newborn losses, so the first 12 hours of newborn life are critical for the stabilization of the normal maternal-offspring bonding process (Vacca et al., 2014). According to this information, refinement feeding status of nanny goats around kidding should be maintained constant levels of suckling milk. Whilst, sudden changes in the diet can cause depart or dulcet feed intake lead to fade or increase suckling milk yield post kidding. Ideally, using natural and healthy feed additives have positive impacts on nutritive value, animal health, and perform. Thus, Khalifa et al. (2014) explained that plant feed additives such as Yucca Schidigera Powder could be improved production, reproduction performance and safely used for long term in dairy nanny goats. One strategy for modification of animals' 


\section{Khalifa et al.}

diet is bioactive feed supplements like microalgae. The most of these microalgae species produce unique products like carotenoids, antioxidants, fatty acids, enzymes, polymers, peptides and sterols (Abu Aita, 2014). Among the most known a microalgae is Spirulina spp. (Arthrospira) belonging to the cyanobacteria, blue-green colored microalgae which are deemed as intermediate species between plant and bacteria (Parimi et al., 2015). The Spirulina platensis powder (SPP) algae has been considered as a suitable nutritional additive because it includes B-complex vitamins, minerals, good quality proteins, gamma-linolenic acid and the super antioxidants, beta-carotene, vitamin E and trace elements (Vishnu and Sumathi, 2014). The most attention has been paid to its potential pharmacological properties of this micro alga to decrease blood cholesterol levels, free radical scavenging (Chu et al., 2010) and also, stimulate the immunological system, reduce the nephrotoxicity of toxic metals and provides protection against the harmful radiation (Yaakob et al., 2014). Earlier study in dairy Lithuanian Black and White cows showed an (supplementation $2 \mathrm{~g}$ of SPP /day/ cow during 60 days) improvement in milk, fat, protein and lactose yields and decrease somatic cell count in comparison with control group (Simkus et al., 2007). Moreover, Heidarpour et al. (2011) studied on suckling calves demonstrated that addition of SPP to diet caused significant reduction in plasma cholesterol concentration while; other blood parameters like the blood urea nitrogen (BUN), albumin and globulin were not affected significant. On other hand, Spirulina platensis can be cultivated in a liquid medium and has been found to out-yield traditional protein-rich feed sources like soybeans, wheat, corn and barley in terms of production per land unit (Borowitzka, 2013). Subsequently, Spirulina platensis addition with basal diets that has been trialed and given goodness results in sheep (Holman et al., 2012) and cattle (Panjaitan et al., 2015).

Therefore, this study is to highlight the roles of Spirulina platensis powder on reproductive performance, udder morphology, suckling milk amount, body weight of does and their kids, commercial milk yield and blood metabolites.

\section{MATERIALS AND METHODS}

This investigate was performed at El-Serw Experimental Research Station using animal herd belongs to Animal Production Research Institute (APRI), Agriculture Research Center, Ministry of Agriculture, Egypt. The study work was managed from May 2014 to April 2015.

\section{Animals and their management}

Pre-breeding season till prenatal, fourteen dairy Zaraibi nanny goats were used to study reproductive performance. All goats had an average live weight $36.00 \pm 0.98 \mathrm{~kg}$ at $33.43 \pm 3.81$ months of age and divided into two groups ( 7 in each). The first group (G1) was control and the second group (G2) serviced as trial group, they received the same basal ration daily that consisted of concentrate fed mixture $(\mathrm{CFM})+$ roughages [as Egyptian berseem hay $(\mathrm{BH})+$ rice straw $(\mathrm{RS})]$. In the morning, two rice paper sacks contained 0 or $500 \mathrm{mg}$ levels of Spirulina platensis powder (SPP) was loaded into and offered to G1 or G2 orally / day / head, respectively.

Table (1): Chemical analysis of CFM, berseem hay and rice straw (on DM basis).

\begin{tabular}{lccc}
\hline Chemical composition (\%) & \multicolumn{3}{c}{ Basal experimental diets } \\
\cline { 2 - 4 } & CFM & BH & RS \\
\hline Organic matter & 91.14 & 85.17 & 84.55 \\
Crude protein & 14.40 & 12.88 & 3.36 \\
Ether extract & 3.04 & 1.68 & 1.24 \\
Crude fiber & 14.30 & 33.91 & 37.50 \\
Nitrogen free extract & 59.40 & 36.70 & 42.45 \\
Ash & 8.86 & 14.83 & 15.45 \\
\hline
\end{tabular}

At postnatal, eight nanny goats were selected from G1 and G2 groups, as well as, in parity rate continued to nourish last similar up to early seven weeks of lactation to investigate changes in body weight of does and their kids, suckling milk amount and composition (i.e. fat \% and protein \%), udder measurements, commercial milk harvest and blood metabolites. The nanny goats were received fresh water, mineral blocks allowed freely and cared under veterinary through all experimental times. The experimental rations were presented according to recommendations of NRC (2007) to cover the nutrient requirements physiological status of goats. The chemical composition of experimental basal rations was 
done according to AOAC (2007) method and presented in Table (1). While, the chemical analysis of SPP had given in Table (2).

Table (2): The chemical composition of Spirulina platensis powder.

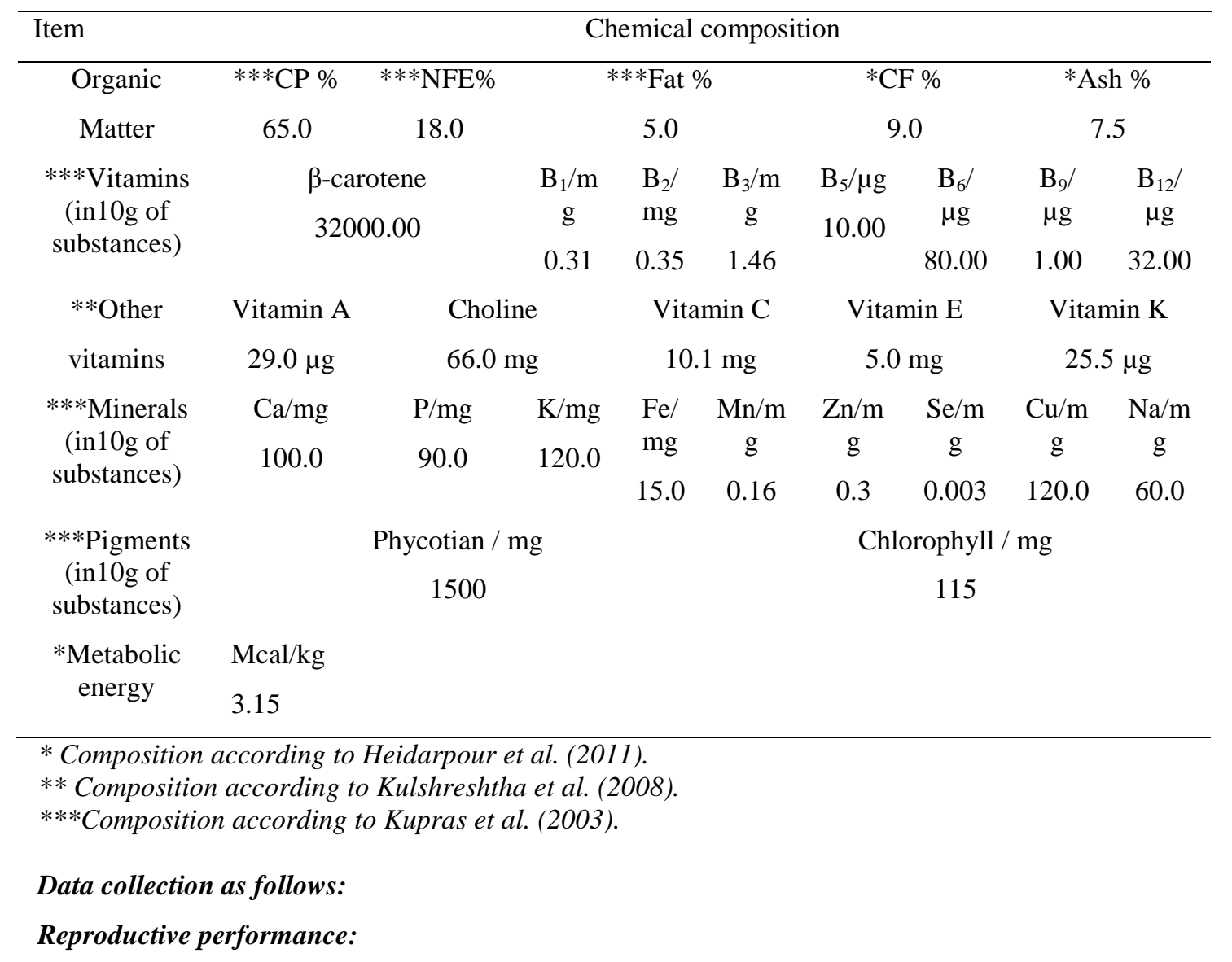

Both G1 and G2 does were received experimental rations twenty-one days pre-breeding (as flushing time) season, during mating season and at trimester (96 days of gestation). The reproductive performance was evaluated as conception rate (number of does conceived /does mated), twins rate (number of does kidded twins / total number of does kidded), triplet rate (number of does kidded triplet / total number of does kidded), quaternary rate (number of does kidded quaternary / total number of does kidded) and litter size $=$ number of total born kids /number of does kidded.

\section{Udder measurement during suckling periods:}

The udder morphology measurements were taken in centimeter $(\mathrm{cm})$ in the morning before feeding when doe adequately restrained in a standing position using flexible tape. The external udder parameters were measured at 0 (after one day of postnatal), 15, 30, 60 and 90 days of parturition. These measurements included udder length, rear udder depth, teat angle, teat length, cistern depth, udder width and udder circumference as illustrated in Fig. (1). Then, udder volume (UV) was derived by using the formula UV $=4 / 3(\pi \times \mathrm{r} \times 3)$ as described by Amao (1999). The values of $\pi=22 / 7$ and $r=[$ udder length + udder width $\div 4]$. 


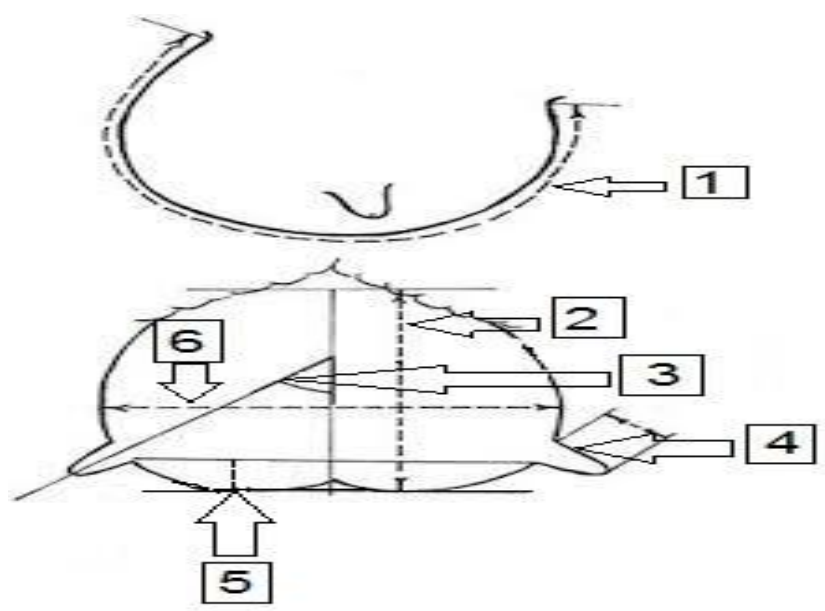

Fig. (1): The does' udder measurements (cm).

1- udder length (UL) , 2-rear udder depth (RUD), 3-teat angle (TA) in degrees from vertical line (intramammary ligament) of the udder from a caudal view using protractor, 4- teat length (TL) using calipers and a metal reference ruler used to determine the diameter, 5- cistern depth (CD), 6- udder width (UW) and udder circumference (UC) was measured circumference of the largest medium area of the udder.

\section{Body weight, suckling milk amount, suckling milk fat, suckling milk protein, suckling milk energy and growth rate of does and their kids:}

Changing in body weight of maternal and their kids recorded at 1 day of birth then, monthly at 30,60 and 90 days of age. The daily gain of does (maternal) and their kids were evaluated between 1 to 30,1 to 60, 1 to 90,30 to 60,30 to 90 and 60 to 90 days. Furthermore, metabolic mid-weight was calculated using this equation $=(\text { initial body weight }(\mathrm{kg})+\text { final body weight }(\mathrm{kg}) \div 2)^{0.75}$ according to Willems et al. (2013)

In addition, daily suckling milk amount evaluated at 7, 15, 30, 60 and 90 days using oxytocin methods described by Khalifa et al. (2013). The suckling milk sample (100 $\mathrm{ml} /$ group) was taken at 15, 30, 45, 60, 75 and 90 days to analysis fat \% and protein \% using Milko-Scan (133B N. Foss Electric, Denmark). Also, the suckling milk energy value $(\mathrm{SMEV}, \mathrm{kcal} / \mathrm{kg})$ was calculated as $=203.8+(8.36 \times$ fat $\%)+(6.29$ $\times$ protein \%) according to Baldi et al. (1992).

\section{Milk yield during early lactation weeks (peak lactation):}

At commencement of lactation after weaning, the total milk yield of a doe /group registered weekly up to seven weeks of lactation. Evaluation daily milk was considered to represent daily milking by added morning cooled milk and the evening milk samples ones.

\section{Blood metabolites:}

Blood samples were collected from the jugular vein at the seventh week of lactation. Eight blood samples (4 / group) were left to clot at room temperature, and then centrifuged at $3000 \mathrm{~g}$ for $20 \mathrm{~min}$. The blood sera were then, separated and stored at $-20^{\circ} \mathrm{C}$ as aliquots for further biochemical analysis. Total protein, glucose, cholesterol, triglyceride, aspartate amino transferase (AST) and alanine amino transferase (ALT) and blood urea were measured using commercial diagnostic kits (BIOLAPO SA, France) and finally measured using the UV spectrophotometer.

\section{Statistical analysis:}

Data were expressed to statistical analysis as means \pm SE using one-way of IBM SPSS (Statistical package for social sciences version 22 Inc, Chicago, 2013). Differences among means were tested according to Duncan's New Multiple Range Test within SPSS program (to determine differences between means of treatments at significance rates of 0.05). Correlation between feeding and mean weaning parameters (represented in does body weight, kids' body weight, udder size, suckling milk flow and energy of suckling milk) were calculated using the Pearson's coefficients of SPSS programmes. 


\section{RESULTS AND DISCUSSION}

\section{Reproductive performance:}

Reproductive performance as the conception rate, multiple offspring and litter size are illustrated in Table (3). The results were indicated that SPP offered to G2 improved total number of kidding (18.00 kids), triple rate $(28.57 \%)$, quaternary rate $(14.29 \%)$ and litter size $(2.71)$ compared to G1 15.00 , $14.29 \%, 00.00 \%$ and 2.14 , respectively. Hence, mix of active substances possessed the ability to boost the reproductive parameter is natural products as the algae (Spirulina platensis) and plants extracts. Such results are in line with Abadjieva et al. (2011) found the SPP indicated that ovary have better response to the hormonal stimulation aimed superovulation thus reflect to the higher embryo outcome. Moreover, SPP could be stimulated steroid genesis and evokes the anterior pituitary gland to the process of secret and release gonadotropin hormones and initiation of folliculogenesis in the ovaries (Yener et al., 2013). The beneficial affects of additive SPP related to the highest protein (EL-Sabagh et al., 2014), vitamin as $\beta$-carotene (Meza-Herrera et al., 2014), minerals mixture (Ahmad Fazel et al., 2014) and energy (Kumar et al., 2015) that played a major protective role in reproductive performance, increased fertility function, played a significant role in ovary cell signaling and immune responses.

Table (3): Reproductive performance of nanny goats in G1 and G2.

\begin{tabular}{lcc}
\hline Parameter & \multicolumn{2}{c}{ Animal groups } \\
\cline { 2 - 3 } & $\mathrm{G} 1$ & $\mathrm{G} 2$ \\
\hline No. of nanny goats mating & 7.00 & 7.00 \\
No. of nanny goats conceived & 7.00 & 7.00 \\
Conception rate, \% & 100 & 100 \\
No. of nanny goats kidding & 7.00 & 7.00 \\
Total no. of kidding & 15.00 & 18.00 \\
Birth type: & & 4.00 \\
No. of nanny goats born twins & 6.00 & 57.14 \\
Twins rate, $\%$ & 85.71 & 2.00 \\
No. of nanny goats born triple & 1.00 & 28.57 \\
Triple rate, $\%$ & 14.29 & 1.00 \\
No. of nanny goats born quaternary & - & 14.29 \\
Quaternary rate, $\%$ & - & 2.71 \\
Litter size, $\%$ & 2.14 & \\
\hline
\end{tabular}

\section{Udder measurement during suckling periods:}

Parameters were estimated from udder morphology of either G1 or G2 are summarized in Table (4). The result of this present study showed that clearly positive significant $(\mathrm{P}<0.05)$ between udder measurements and feeding SPP during 90 days of suckling. The G2 were achieved the highest udder formation compare to G1. This observation may be due to changes in tissue elasticity in the mammary gland which caused by placental hormones during gestation when SPP supplied. Mahboub et al. (2013) established an elevated and a positive correlation between placental hormones and placental development, expressed as a function of weight or size of udder and milk production. Further, energy in SPP may cause the majority of morphological and physiological development of the mammary gland under strict control of endocrinal factors and energy balance (Gregorio et al., 2014). In addition, feeding of SPP to G2 could provide organic trace minerals especially zinc which maintaining udder health and integrity of skin due to its role in cellular repair and replacement and by increasing the speed of wound healing. This notion are defined by Davidov et al. (2013) who explained that after zinc absorbed; it transports to blood and whole body, including udder then increased concentrations of zinc in serum or whole blood have been related to 
Khalifa et al.

Table (4): Udder measurement during suckling periods in G1 and G2.

\begin{tabular}{|c|c|c|c|c|c|c|c|c|c|}
\hline \multirow{2}{*}{$\begin{array}{c}\text { Evaluation } \\
\text { days }\end{array}$} & \multirow{2}{*}{$\begin{array}{l}\text { Trial } \\
\text { groups }\end{array}$} & \multicolumn{8}{|c|}{ Udder measurements } \\
\hline & & $\mathrm{UL}$ & RUD & UW & $\mathrm{UC}$ & $\mathrm{CD}$ & TL & TA & US \\
\hline At & G1 & $35.25^{\mathrm{b}}$ & 23.75 & $18.25^{b}$ & $39.00^{b}$ & $7.50^{\mathrm{b}}$ & 5.75 & $36.75^{\mathrm{a}}$ & $160.89^{b}$ \\
\hline \multirow[t]{3}{*}{0 day } & & \pm 1.70 & \pm 1.03 & \pm 0.25 & \pm 1.41 & \pm 0.86 & \pm 0.47 & \pm 1.75 & \pm 7.09 \\
\hline & $\mathrm{G} 2$ & $43.25^{\mathrm{a}}$ & 25.00 & $20.00^{\mathrm{a}}$ & $43.00^{\mathrm{a}}$ & $9.25^{\mathrm{a}}$ & 5.75 & $32.50^{\mathrm{b}}$ & $195.43^{\mathrm{a}}$ \\
\hline & & \pm 0.47 & \pm 0.41 & \pm 0.40 & \pm 0.42 & \pm 0.25 & \pm 0.48 & \pm 1.44 & \pm 1.64 \\
\hline At & G1 & $35.00^{\mathrm{b}}$ & $19.25^{\mathrm{b}}$ & $17.75^{\mathrm{b}}$ & $35.25^{\mathrm{b}}$ & $6.25^{\mathrm{b}}$ & $3.75^{b}$ & 40.00 & $159.48^{b}$ \\
\hline \multirow[t]{3}{*}{15 days } & & \pm 2.40 & \pm 1.84 & \pm 0.24 & \pm 1.37 & $0.63 \pm$ & \pm 0.25 & \pm 2.04 & \pm 10.37 \\
\hline & $\mathrm{G} 2$ & $40.50^{\mathrm{a}}$ & $24.50^{\mathrm{a}}$ & $18.75^{\mathrm{a}}$ & $39.50^{\mathrm{a}}$ & $7.75^{\mathrm{a}}$ & $4.50^{\mathrm{a}}$ & 38.75 & $183.19^{\mathrm{a}}$ \\
\hline & & \pm 0.62 & \pm 1.32 & \pm 0.24 & \pm 0.29 & \pm 0.48 & \pm 0.28 & \pm 1.25 & \pm 2.83 \\
\hline At & G1 & $31.50^{\mathrm{b}}$ & 18.50 & $17.25^{\mathrm{b}}$ & $32.75^{b}$ & $5.00^{\mathrm{b}}$ & 4.00 & 43.75 & $144.49^{b}$ \\
\hline \multirow[t]{3}{*}{30 days } & & \pm 1.44 & \pm 1.26 & \pm 0.84 & \pm 1.11 & \pm 0.09 & \pm 0.70 & \pm 2.39 & \pm 5.92 \\
\hline & $\mathrm{G} 2$ & $35.50^{\mathrm{a}}$ & 21.25 & $20.50^{\mathrm{a}}$ & $38.75^{\mathrm{a}}$ & $6.25^{\mathrm{a}}$ & 4.25 & 41.42 & $163.63^{a}$ \\
\hline & & \pm 1.04 & \pm 0.85 & \pm 0.65 & \pm 0.75 & \pm 0.28 & \pm 0.25 & \pm 1.25 & \pm 3.93 \\
\hline At & G1 & $31.50^{\mathrm{b}}$ & 18.75 & $19.25^{b}$ & $32.00^{\mathrm{b}}$ & 5.75 & 4.00 & 48.75 & $145.99^{b}$ \\
\hline \multirow[t]{3}{*}{60 days } & & \pm 1.19 & \pm 0.85 & \pm 0.25 & \pm 1.47 & \pm 0.63 & \pm 0.09 & \pm 1.25 & \pm 4.78 \\
\hline & $\mathrm{G} 2$ & $35.75^{\mathrm{a}}$ & 20.75 & $20.75^{\mathrm{a}}$ & $37.25^{\mathrm{a}}$ & 6.75 & 4.00 & 45.00 & $164.86^{\mathrm{a}}$ \\
\hline & & \pm 0.85 & \pm 0.48 & \pm 0.63 & \pm 0.85 & \pm 0.25 & \pm 0.08 & \pm 2.04 & \pm 3.72 \\
\hline At & G1 & $27.75^{b}$ & $16.25^{\mathrm{b}}$ & 16.75 & $28.50^{\mathrm{b}}$ & $4.50^{\mathrm{b}}$ & 3.50 & $51.50^{\mathrm{a}}$ & $128.45^{b}$ \\
\hline \multirow[t]{3}{*}{90 days } & & \pm 0.95 & \pm 0.75 & \pm 0.63 & \pm 1.56 & \pm 0.64 & \pm 0.29 & \pm 2.39 & \pm 3.83 \\
\hline & G2 & $30.75^{\mathrm{a}}$ & $18.25^{\mathrm{a}}$ & 18.50 & $32.00^{\mathrm{a}}$ & $6.00^{\mathrm{a}}$ & 4.00 & $45.00^{\mathrm{b}}$ & $142.29^{\mathrm{a}}$ \\
\hline & & \pm 0.85 & \pm 0.25 & \pm 0.28 & \pm 1.29 & \pm 0.41 & \pm 0.08 & \pm 2.04 & \pm 3.39 \\
\hline
\end{tabular}

Means within the same columns with different superscripts are significantly different $(P<0.05)$.

Udder length (UL), rear udder depth (RUD), udder width $(U W)$, udder circumference (UC), cistern depth $(C D)$, teat length (TL), teat angle (TA) and udder size (US).

reduce somatic cell count, reduced mastitis and improved immunological function of udder. Accordingly, nourishment of SPP to G2 might protect udder tissues and renovation udder cells by free radical scavenging that attributed the most udder parameters by kept tissues flexible and extended (Yaakob et al., 2014). It is important to mention this result, the relationship between udder traits and dairy performance was strong however, udder length (UL) and udder depth (UD) are more associated with the total milk produced per lactation and length. Hence, the evaluation of udder morphology might be useful auxiliary traits for the genetic improvement of milking ability due to close genetic correlations (Sadeghi et al., 2014). In any event, Akporhuarho (2015) concluded that the size of udder during lactation achieved significant determinant of average partial daily milk yield and the regression analysis revealed that udder circumference (UC) was the most important single measurement accounted for over $22 \%$ of variation of partial daily milk yield in West African Dwarf goat. On the other hand, Hafez et al. (2015) indicated that positive relationship between either feed type or udder formation or suckling milk amount or growth rate of Rahmani lambs.

Suckling milk amount, suckling milk fat, suckling milk protein, suckling milk energy and growth rate of does and their kids:

Productive performance during suckling period such as suckling milk yield, its fat content, protein content and energy content as affected by dietary treatments are presented in Figs (1), (2 and 3) and (4), respectively. Furthermore, average growth rate of does and their kid are calculated in Tables (5 and 6), respectively. 


\section{Suckling milk amount:}

The greatest values of suckling milk observed in G2 at all 90 days; which may attribute to improvement of udder measurements compared to G1 (Table 4). The statistically data were appeared high $(\mathrm{P}<0.05)$ in suckling milk amounts at 7 days (2975 and 2025g), 60 days (2400 and $1500 \mathrm{~g})$ and 90 days (1950 and $1500 \mathrm{~g}$ ) for G2 and G1, respectively. However, suckling milk amount shown non-significant values among G1 and G2 at 15 and 30 days of suckling periods. Otherwise, the suckling milk between 7 and 90 days had increased by $34.35 \%$ and $25.92 \%$ in G2 and G1, respectively. Actually, higher udder measurement in G2 could receive large amounts of blood biochemical than G1; which important indicators of the metabolic activity in lactating animals. This mention agree with carried out by Darwesh et al. (2013) who observed that during lactation, secretary cells of mammary gland utilize $80 \%$ of the blood circulating metabolites for milk synthesis, depending on the speed of infiltration of precursors of milk compounds (i.e. free amino acids, glucose and fatty acids). Accordingly, authors reported that SPP could improve milk amount in lactation cows (Christaki et al., 2012). In addition, the ingredients of SPP as zinc appeared an essential function in milk amount. Similar trends were obtained by Davidov et al. (2013) on dairy cows that zinc plays an important role in the proper function of the first mechanism of milk products and it also affects the degree of keratinisation of the teat canal, thereby protecting the udder against bacterial penetration after milking. A related study demonstrated that deficiency of $\mathrm{Zn}$ was a result of the depression in appetite of animals and consequently milk yield, feed dry matter intake, digestibility and nutritive feed values which reflect on the decrease of the available nutrients to the mammary gland.

\section{Suckling milk fat, suckling milk protein and suckling milk energy:}

The highest $(\mathrm{P}<0.05)$ effect of suckling milk energy in $\mathrm{G} 2$ related to significantly $(\mathrm{P}<0.05)$ greater values of suckling milk fat (Fig. 2) and protein contents (Fig. 3) than G1 noticed in Fig. (4). Similarly, Simkus et al, (2007) showed an increase in milk fat (between 17.6\% and 25.0\%), milk protein (up by 9.7\%) and lactose (up by $11.7 \%$ ) in cows receiving Spirulina compared to those non- receiving Spirulina. The current results are in agreement with those observed in milk of cows fed SPP (Christaki et al., 2012) revealed that dietary Spirulina increased monounsaturated and polyunsaturated fatty acids and enhancement milk with health-associated unsaturated fatty acids. Also, the highest average sucking milk protein $(2.69 \%)$ in G2 compared to $(2.39 \%)$ in G1 might be related to boost essential amino acids and protein content in SPP (Parimi et al., 2015).

\section{Growth rate of does and their kids:}

In response to the addition of SPP in $\mathrm{G} 2$, it presents the greatest $(\mathrm{P}<0.05)$ average body weight during suckling period compared with those does in G1. However, average daily gains (ADG) of G2 appeared higher $(\mathrm{P}>0.05)$ values than $\mathrm{G} 1$ except ADG between 60 and 90 days it was 41.67 and $66.67 \mathrm{~g} / \mathrm{day}$, respectively (Table 5). This result confirms the findings of Holman et al. (2012) indicated that an increase in live weight of sheep with dietary Spirulina along with an increase in body condition and other body conformation traits. Interestingly, improvement growth rate of does fed SPP ration was associated with increasing digestibility coefficients of most nutrients and nutritive values of this ration as compared to other not receive SPP rations. This corresponds to the opinion of Panjaitan et al. (2014) who stated that Spirulina intake with $5.7 \mathrm{~g}$ could be provided greater increases microbial crude protein (MCP) production, feed intake, could also be fed safely at higher levels of nitrogen $(\mathrm{N})$ intake, increasing rumen degradable protein (RDP) and growth rate in cattle. The findings from the current study established that kids nursed by G2 showed higher average body weight and daily gain without significant than those auspices in G1. However at birth, care kids by G2 nanny goats showed significantly $(\mathrm{P}<0.05)$ higher in average body weight than kids patronage by G1 (Table 6). This difference is certainly related to the respective milk production (quality and quantity) in G2 compared to G1. Hence, feeding of SPP to pregnant does provided adequate energy, protein, minerals, vitamins to support embryonic, fetal growth, maintenance of metabolic processes, mammary gland growth, colostrum and milk yield. These studies go along with the evidence of Mahboub et al. (2013) who noticed that the best nutritional during fetal life effects on postnatal growth, reproductive performance and metabolism. On the other hand, milking of Spirulina animals contains phycocyanin and polysaccharides, both known to have antioxidant properties. In generally, SPP energy could display better growth performance (by secretion leptin hormones) in G2 and their kids than G1. These results are in identity with those reported by Gregorio et al. (2014) who indicated that leptin helps of metabolism, preventable negative energy balance, activates growth rate and builds mammary epithelial cells during early phase of pregnancy and lactation. 
Fig. 1: Suckling milk amount of nanny goats fed either control (G1) or treatment diet (G2).

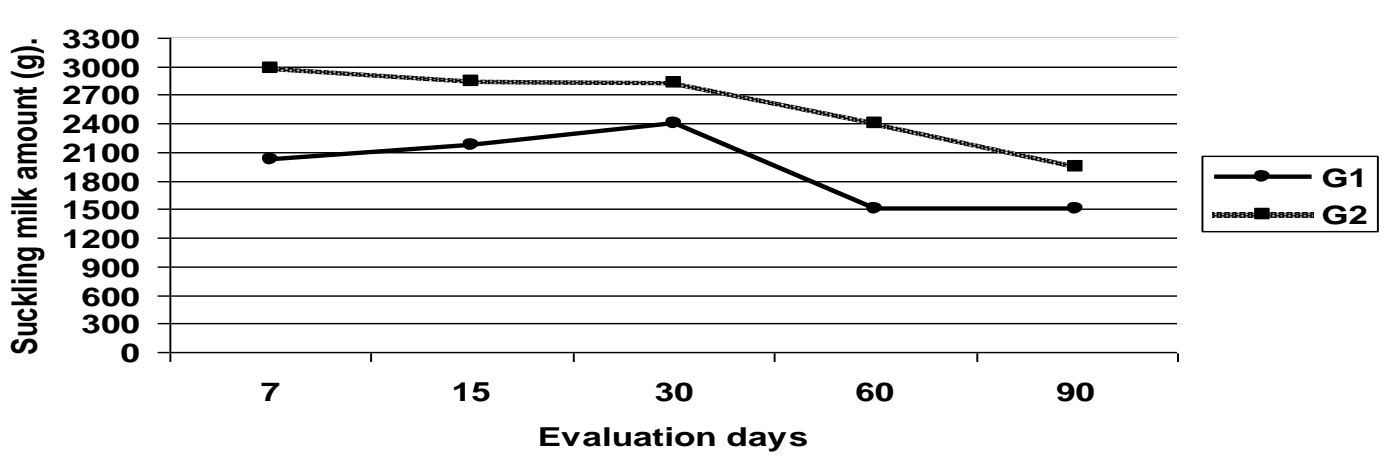

Fig.2: Suckling milk fat \% of nanny goats fed either control (G1) or treamtment diet (G2).

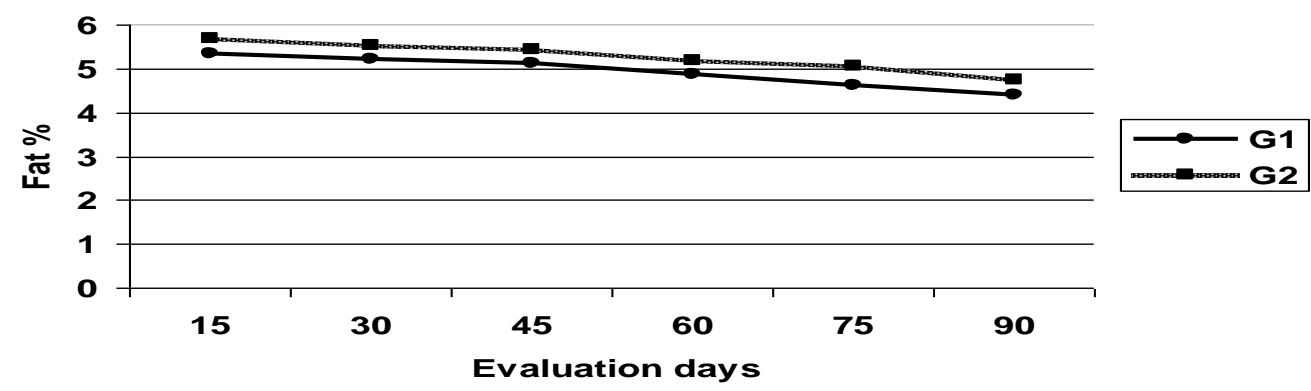

Fig.3: Suckling milk protein \% of nanny goats either control (G1) or treatment diet (G2).

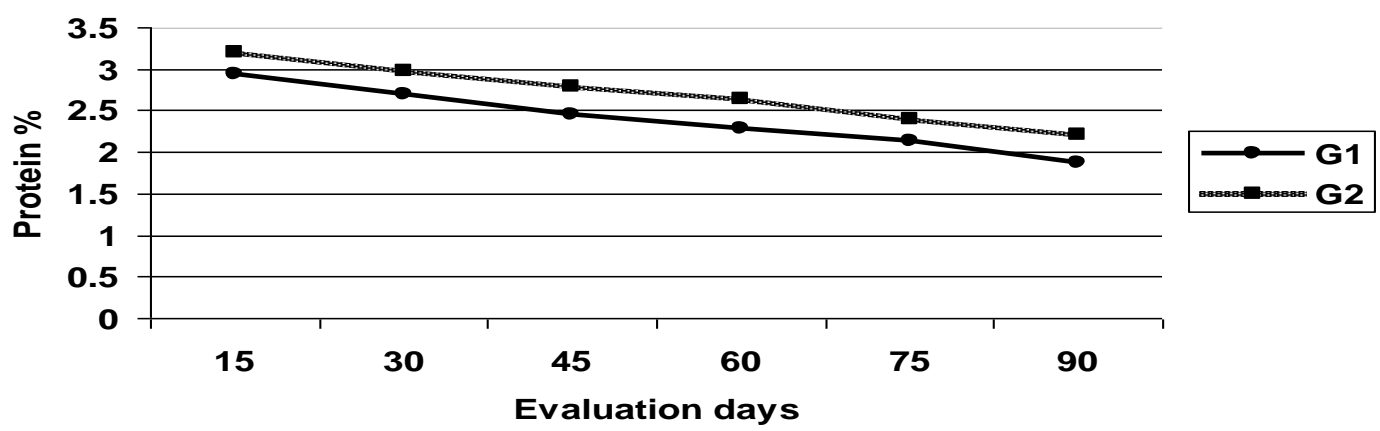

Fig.4: Suckling milk energy of nanny goats fed either control (G1) or treatmemt diet (G2).

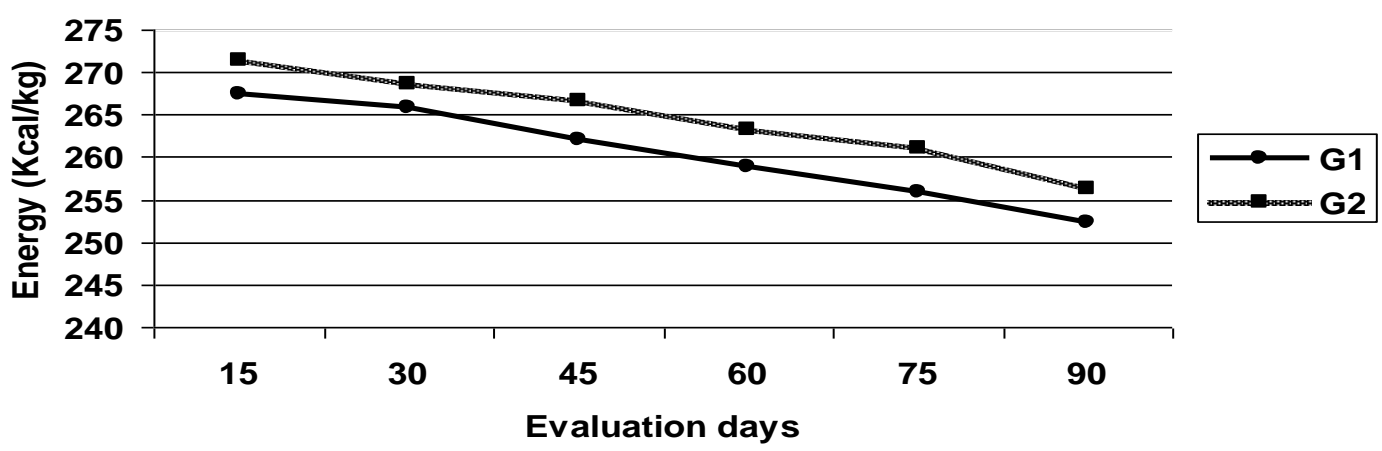


Table (5): Body weight and daily gain of dams in G1 and G2.

\begin{tabular}{lcc}
\hline Specification & \multicolumn{2}{c}{ Animal groups } \\
\cline { 2 - 3 } & G1 & G2 \\
\hline Body weight at parturition as day 1, kg & $42.25 \pm 2.14^{\mathrm{b}}$ & $47.25 \pm 1.03^{\mathrm{a}}$ \\
Body weight at 30 days, $\mathrm{kg}$ & $39.00 \pm 1.58^{\mathrm{b}}$ & $43.75 \pm 0.75^{\mathrm{a}}$ \\
Body weight at 60 days, $\mathrm{kg}$ & $37.50 \pm 1.32^{\mathrm{b}}$ & $41.75 \pm 0.25^{\mathrm{a}}$ \\
Body weight at 90 days, $\mathrm{kg}$ & $36.25 \pm 1.11^{\mathrm{b}}$ & $39.75 \pm 0.24^{\mathrm{a}}$ \\
Metabolic mid-weight, kg & $21.66 \pm 1.26$ & $23.45 \pm 1.32$ \\
Daily gain of dams (g/d) & & \\
1-30 days & $112.07 \pm 21.69$ & $120.69 \pm 19.95$ \\
1-60 days & $80.51 \pm 14.47$ & $93.22 \pm 14.71$ \\
1-90 days & $67.42 \pm 12.14$ & $84.27 \pm 8.42$ \\
30-60 days & $50.00 \pm 9.62$ & $66.67 \pm 9.25$ \\
30-90 days & $45.83 \pm 7.98$ & $66.67 \pm 9.17$ \\
60-90 days & $41.67 \pm 6.84^{\mathrm{b}}$ & $66.67 \pm 7.13^{\mathrm{a}}$ \\
\hline
\end{tabular}

Means within the same row with different superscripts are significantly different $(P<0.05)$.

Table (6): Body weight growth and daily gain of kids depending on suckling milk in G1 and G2.

\begin{tabular}{lcc}
\hline Specification & \multicolumn{2}{c}{ Animal groups } \\
\cline { 2 - 3 } & $\mathrm{G} 1$ & $\mathrm{G} 2$ \\
\hline Body weight of kid at birth as day 1, kg & $1.99 \pm 0.13^{\mathrm{b}}$ & $2.39 \pm 0.17^{\mathrm{a}}$ \\
Body weight of kid at 30 days, $\mathrm{kg}$ & $5.83 \pm 0.26$ & $6.58 \pm 0.42$ \\
Body weight of kid at 60 days, $\mathrm{kg}$ & $8.53 \pm 0.30$ & $9.31 \pm 0.47$ \\
Body weight of kid at 90 days, $\mathrm{kg}$ & $10.46 \pm 0.56$ & $11.34 \pm 0.73$ \\
Metabolic mid-weight of kid, kg & $4.40 \pm 0.46$ & $4.78 \pm 0.52$ \\
Daily gain of kids (g/d) & & \\
1-30 days & $132.37 \pm 7.70$ & $144.18 \pm 9.93$ \\
1-60 days & $110.83 \pm 5.11$ & $117.16 \pm 6.46$ \\
1-90 days & $95.24 \pm 5.69$ & $100.49 \pm 6.72$ \\
30-60 days & $90.00 \pm 11.81$ & $91.04 \pm 7.43$ \\
30-90 days & $77.29 \pm 5.88$ & $79.38 \pm 5.70$ \\
60-90 days & $64.58 \pm 17.84$ & $67.71 \pm 12.10$ \\
\hline
\end{tabular}

Means within the same row with different superscripts are significantly different $(P<0.05)$.

Correlation coefficients between feeding and does body weight, kids' body weight, udder size, suckling milk flow and energy of suckling milk:

In Table (7), it could be concluded that correlation coefficients between feeding and does body weight, kids' body weight, udder size, suckling milk flow and energy of suckling milk reflected positively correlation. The udder volume revealed significant effect on weaning weight and growth rate of kids. Thus, the results allow possibility to predict milk yield of does from the linear regression of udder confirmation. These results agree with what stated by El-Gendy et al. (2014) who reported in Zaraibi and

Table (7): Correlation coefficient among feeding and weight of does and their kids, suckling milk and udder volume.

\begin{tabular}{lcccccc}
\hline Item & Feeding & BWD & BWK & UV & SMA & SME \\
\hline Feeding & 1 & 0.571 & 0.563 & 0.578 & 0.684 & 0.515 \\
BWD & & 1 & $1.000^{* *}$ & $1.000^{* *}$ & 0.990 & $0.998^{*}$ \\
BWK & & & 1 & $1.000^{* *}$ & $0.998^{*}$ & $0.998^{*}$ \\
UV & & & & 1 & $0.991^{*}$ & $0.997^{* *}$ \\
SMA & & & & & 1 & 0.978 \\
\hline
\end{tabular}

$B W D=$ Body weight of does at weaning, $B W K=$ body weight of kids at weaning, $U V=$ udder volume at weaning, $S M A=$ suckling milk amount at weaning and $S M E=$ suckling milk energy at weaning.

*Correlation is significant at the $(P<0.05)$.

$* *$ Correlation is significant at the $(P<0.01)$. 


\section{Khalifa et al.}

Damascus dairy goats, significant correlations between udder traits and milk yield and kid growth rate. It was observed that the noticed improvement in milk yield of does fed SPP ration was associated with increasing udder measurements and growth rate of dams and their kids (Vishnu and Sumathi, 2014, Akporhuarho, 2015 and Hafez et al., 2015).

\section{Milk yield during early lactation weeks (peak lactation)}

The overall means of milk production throughout seven weeks of lactation was $3.704 \mathrm{~kg}$ in the G1 and $5.297 \mathrm{~kg}$ in the $\mathrm{G} 2$ and the difference was found to be statistically significant $(\mathrm{P}<0.05)$ among groups during first three weeks of lactation (Fig. 5). While, advancing of lactation curve another four weeks does in G2 was appeared non-significantly booster in milk harvest than those does in G1. Hence, the milk production was affected by orally SPP nutrition to nanny goats. Thus, these results are reported by other authors show certain differences in this respect (Christaki et al., 2012). According to Yaakob et al. (2014) demonstrated that spirulina has been frequently used in feed supplements due to its excellent nutrient compounds and digestibility, also found that the spirulina has proved to be effective significantly an increased milk yield.

Fig. 5:Lactation milk amount of nanny goats fed either control (G1) or treatment diet (G2).

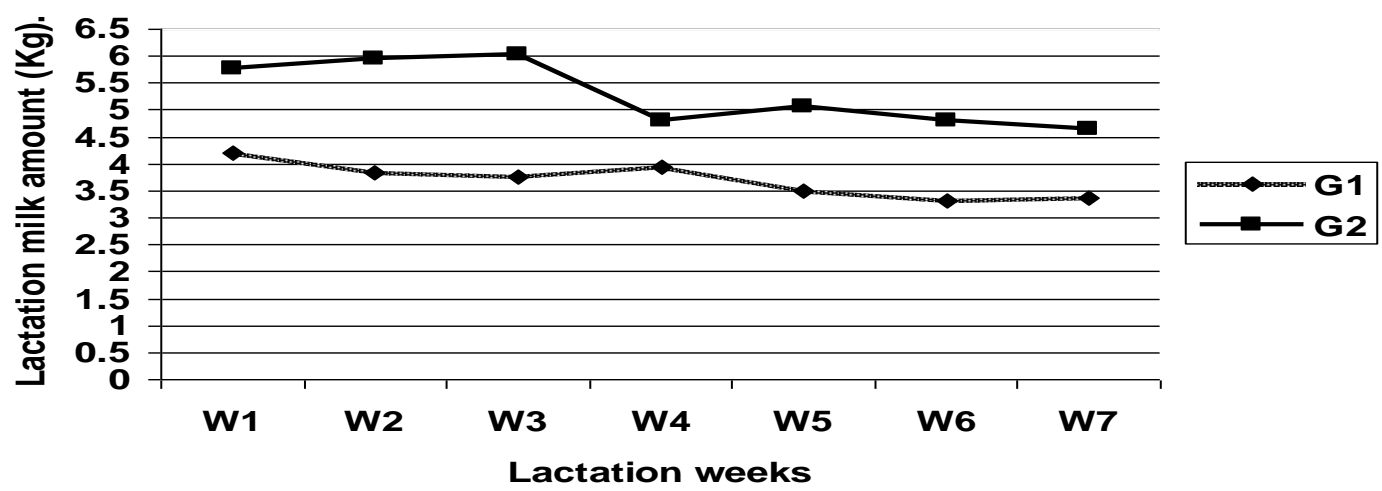

\section{Blood metabolite parameters:}

The significant differences $(\mathrm{P}<0.05)$ of the blood biochemical concentrations such as total protein, glucose, cholesterol, triglycerides, AST and ALT were found between the G1 and G2. Moreover, there was no significant difference in the concentrations of urea among G1 and G2 Table (8). Addition of SPP to $\mathrm{G} 2$ induced high significant elevation $(\mathrm{P}<0.05)$ in total protein, glucose while significantly reduced $(\mathrm{P}<0.05)$ the cholesterol, triglycerides, AST and ALT concentrations compared to G1. Furthermore, increasing $(\mathrm{P}>0.05)$ in urea with an unexpected increase in total protein concentrations in $\mathrm{G} 2$. In the present study there was higher total protein concentration in blood of G2 than those in G1. Increasing concentrations of total protein may be related to the high protein contents in Spirulina (Parimi et al., 2015). On the other hand, SPP has been reported to ameliorate total protein levels without any risk in kidneys function of lambs (EL-Sabagh et al., 2014). The results demonstrated that blood glucose level in G1 was drastically reduced to $56.25 \mathrm{mg} / \mathrm{dI}$ compared to $\mathrm{G} 2$ it was significantly increased to $60.50 \mathrm{mg} / \mathrm{dI}$. These results are in accordance with those noted by Liping et al. (2011) who defined that blood glucose concentration of rat was significantly increased 128.1, 157.8, 167.4 and 171.5 and $\mathrm{mg} / \mathrm{dl}$ when SP supplemented at levels $0,50,100$ and $200 \mathrm{mg} / \mathrm{kg}$ for 6 weeks, respectively. Also, these authors reported that gluconeogenesis carries out the major role of glucose homeostasis in endurance exercise and SPP addition must be brought about by an improvement in the physiological function or metabolic control of exercise as well as by an activation of energy metabolism. The blood cholesterol levels of G2 were 77.75 $\mathrm{mg} / \mathrm{dl}$, which significantly decreased compared to that in the $\mathrm{G} 183.25 \mathrm{mg} / \mathrm{dl}$. Otherwise, the hypercholesterolemia activity of spirulina is related to the large amount of cystine found in the Cphycocyanin protein of spirulina hence, a negative correlation was reported between the blood cholesterol concentrations and the level of cystine in dietary protein in mice fed a high cholesterol diet (Vedi et al., 2013). There was significant difference among triglycerides concentration, the unexpected decrease in the triglycerides in G2 in this study may imply that the SPP might be exerted its lipid-modulating properties. So, the mechanism in which SPP plays a significant role in lipid metabolism should not be directly due to its lipid contents. Ruitang and Chu (2010) in human triglycerides reduction has been stated as the effect 
of SPP on lipoproteins metabolism and the increase of the lipoprotein enzyme activity levels. Results of the current study were found that SPP showed slight high without significant in blood urea in G2 goat

Table (8): Blood metabolites parameters in G1 and G2.

\begin{tabular}{lcc}
\hline Parameters & \multicolumn{2}{c}{ Animal groups } \\
\cline { 2 - 3 } & $\mathrm{G} 1$ & $\mathrm{G} 2$ \\
\hline Total protein, g/dI & $5.50 \pm 0.29^{\mathrm{b}}$ & $6.25 \pm 0.25^{\mathrm{a}}$ \\
Glucose, mg/dI & $56.25 \pm 0.25^{\mathrm{b}}$ & $60.50 \pm 0.65^{\mathrm{a}}$ \\
Cholesterol, mg/dI & $83.25 \pm 0.48^{\mathrm{a}}$ & $77.75 \pm 0.47^{\mathrm{b}}$ \\
Triglyceride, mg/dI & $81.25 \pm 0.25^{\mathrm{a}}$ & $74.75 \pm 0.48^{\mathrm{b}}$ \\
Urea, mg/Di & $22.50 \pm 0.28$ & $23.75 \pm 0.25$ \\
AST, U/l & $184.25 \pm 0.48^{\mathrm{a}}$ & $175.00 \pm 1.08^{\mathrm{b}}$ \\
ALT, U/l & $15.50 \pm 0.64^{\mathrm{a}}$ & $11.50 \pm 0.65^{\mathrm{b}}$ \\
\hline
\end{tabular}

Means within the same row with different superscripts are significantly different $(P<0.05)$.

$(23.75 \mathrm{mg} / \mathrm{dl})$ compared to those does in G1 $(22.50 \mathrm{mg} / \mathrm{dl})$. Hence, the SPP itself significantly improved the damages of hepatocytes and renal tissues specifically glomerulus filtration for they normalized the activities of these hepato-renal markers. At all events, the blood urea levels recorded in this study were within the reference of urea values $(12-28 \mathrm{mg} / \mathrm{dl})$ for normal goats reported by Kalio et al. (2014). On the other hand, Liping et al. (2011) found that the urea concentration were 8.68, 6.25, 6.01, $5.84 \mathrm{mmol} / \mathrm{L}$ when rat received SPP at levels at $0,50,100$ and $200 \mathrm{mg} / \mathrm{kg}$, respectively. The parameters of SAT and ALT were consistent with the references reported that normal range of liver enzymes. The AST level was varied from 167 to 513 U/l while, ALT between 9 and 19 U/l (Rumosa-Gwaze et al., 2012). In the present study, G2 showed a significant decrease in AST (175.00U/1) and ALT (11.50 U/l) compared with G1 that obtained that AST (184.25 U/l) and ALT (15.50U/1). This result is symmetrical with Azab et al. (2013) who indicated that SPP may play a protective role against liver dysfunctions. On the other hand, Mazokopakis et al. (2014) reported that spirulina supplementation in human food has strong and multiple beneficial metabolic effects and improves mean levels of AST, ALT, triglycerides and total cholesterol were significantly decreased: $38.5 \%, 37.5 \%, 24.8 \%$ and $9.1 \%$ respectively, whereas the mean levels of high-density lipoprotein and hemoglobin were significantly increased: $4.2 \%$ and $4.1 \%$ respectively.

\section{Economic efficiency of milk production during seven weeks:}

Economic estimation of rations and milk production whole seven weeks of lactation period are presented in Table (9). The economic efficiency of milk production during seven weeks of lactation was depended on offered ration to either G1 or G2 as $1.200 \mathrm{~kg}$ of CFM at 8.00 a.m., $1.000 \mathrm{~kg}$ of BH twice daily (500 g at $11.00 \mathrm{a} . \mathrm{m}$. and $500 \mathrm{~g}$ at $3.00 \mathrm{p} . \mathrm{m}$.), RS $300 \mathrm{~g}$ all day and $500 \mathrm{mg} / \mathrm{G} 2$ daily in the morning. The current results obtained that milk yield / feed efficiency and feed conversion for G2 was the best while, those fed the control ration showed the poorest values. The cost of $\mathrm{kg}$ milk was the lowest (1.45 L.E) for doe in G2 and the highest (1.84 L.E) for the G1 does. Interestingly, such trend was reflected in the highest economic efficiency (\%) of milk production 55.96 and 44.15 in G2 followed by those in G1, respectively. Furthermore, G2 was obtained higher economic efficiency relative (127.27 \%) than control (G1).

\section{CONCLUSION}

The result of the present study tends to show that SPP improved reproductive performance, suckling milk (quantity and quality), live body weight gain of nanny goats and their weaning kids. The SPP could be mitigated liver enzyme activities, cholesterol, triglycerides and increased total protein, glucose without organics dysfunction. Also, SPP indicated slightly increasing in urea concentration despite high total protein. Hence, SPP could currently be used as an additive food substance without adverse impact on dairy goats and their offspring. 
Table (9): Economic efficiency of milk production in G1 and G2 during peak lactation.

\begin{tabular}{|c|c|c|}
\hline \multirow[t]{2}{*}{ Item } & \multicolumn{2}{|c|}{ Animal groups } \\
\hline & G1 & G2 \\
\hline CFM intake during seven weeks, $\mathrm{kg} / 4$ does & 235.20 & 235.20 \\
\hline $\mathrm{BH}$ intake during seven weeks, $\mathrm{kg} / 4$ does & 196.00 & 196.00 \\
\hline $\mathrm{RS}$ intake during seven weeks, $\mathrm{kg} / 4$ does & 58.80 & 58.80 \\
\hline SPP intake during seven weeks, $\mathrm{kg} / 4$ does & - & 0.098 \\
\hline Total nutrients intake, $\mathrm{kg} / \mathrm{doe}^{\mathrm{A}}$ & 490.000 & 490.098 \\
\hline \multicolumn{3}{|l|}{ Cost of rations intake and sale milk, LE } \\
\hline Cost of CFM /4 does & 611.52 & 611.52 \\
\hline Cost of $\mathrm{BH} / 4$ does & 137.20 & 137.20 \\
\hline Cost of RS/ 4 does & 14.72 & 14.72 \\
\hline Cost of SPP/ 4 does & - & 98.00 \\
\hline Total cost of rations intake / 4 does ${ }^{B}$ & 763.44 & 861.44 \\
\hline Total milk yield / 4 does, $\mathrm{kg}^{\mathrm{C}}$ & 103.72 & 148.32 \\
\hline Price of sale milk, $\mathrm{LE}^{\mathrm{D}}$ & 337.09 & 482.04 \\
\hline \multicolumn{3}{|l|}{ Economic efficiency } \\
\hline Feed efficiency, ${ }^{\mathrm{C} / \mathrm{A}}$ & 0.21 & 0.30 \\
\hline Feed conversion, ${ }^{\mathrm{A} / \mathrm{C}}$ & 4.72 & 3.30 \\
\hline Feeding cost of producing milk / 4 does ${ }^{\mathrm{B} / \mathrm{C}}$ & 7.36 & 5.81 \\
\hline *Feeding cost of producing $\mathrm{kg}$ milk /doe & 1.84 & 1.45 \\
\hline Economic efficiency (EE), ${ }^{\mathrm{D} / \mathrm{B}}$ & 0.44 & 0.56 \\
\hline$* *$ Economic efficiency (EE), \% & 44.15 & 55.96 \\
\hline$* * * \mathrm{EE}(\%)$ relative to control & 100.00 & 127.27 \\
\hline
\end{tabular}

\section{REFERENCES}

Abadjieva, D., K. Shumkov, E. Kistanova, D. Kacheva and B. Georgiev (2011). Opportunities for the improvement of the reproductive performances in female animals. Biotechnology in Animal Husbandry. 27 (3): 365-372.

Abu Aita, Nashwa A. (2014). Hepatoprotective effect of spirulina platensis against aluminum chloride induced liver damage in rats. Global Veterinaria. 13 (4): 552 -559.

Ahmad Fazel, A., H.D. Kia, A. Hosseinkhani, G. Moghaddam, S. Alijani and A. Olfati (2014). Investigating the effectiveness of nutrition on the sexual and breeding behaviors in Ghezel sheep. International journal of Advanced Biological and Biomedical Research. 2 (3): 715 - 722.

Akporhuarho, P.O. (2015). Assessments of udder size and milk yield of West African Dwarf (WAD) goats reared under semi intensive management system in Humid Nigeria. Global Journal of Animal Scientific Research. 3 (1): 36 - 40.

Amao, O.A. (1999). Evaluation of udder traits in West African Dwarf and Red Sokoto goats. M. Agric. Thesis Department of Animal production and Health, University of Agriculture, Abeokuta, Nigeria.

AOAC. (2007). Association of Official Analytical Chemists. Official Methods of Analysis. 19 ${ }^{\text {th }}$ Edition. Washington, DC: AOAC. USA.

Azab, S., M. Abdel-Daim and O. Eldahshan (2013). Phytochemical, cytotoxic, hepatoprotective and antioxidant properties of Delonix regia leaves extract. Med. Chem. Res., 22: 4269 - 4277.

Baldi, A., F. Cheli, C. Corino, V. Dell'Orto and F. Polidor (1992). Effects of feeding calcium salts of long chain fatty acids on milk yield, milk composition and plasma parameters of lactating goats. Small Rumin Res., 6: 303 - 310. 
Borowitzka, M.A. (2013). High-value products from microalgae their development and commercialization. Journal of Applied Phycology. 1: 1-14.

Christaki, E., M. Karatzia, E. Bonos, P. Florou-Paneri and C. Karatzias (2012). Effect of Spirulina plantensis on milk fatty acid profile of dairy cows. Asian J. of Anim. \& Vet. Advances. 7 (7): 597 604.

Chu, W. L., Y.W. Lim, A.K. Radhakrishnan and P.E. Lim (2010). Protective effect of aqueous extract from Spirulina platensis against cell death induced by free radicals. BMC Complementary and Alternative Medicine.10 (53): 2 - 8.

Darwesh, K.A., K.Y. Merkhan and E.T.S. Buti (2013). Impact of lactation stage on the body condition and milk quality of Black goat. International Journal of Agricultural and Food Research. 2 (2): 48 52.

Davidov, I., M. Radinović, M. Erdeljan, M.R. Cincović, I. Stančić and B. Belić (2013). Relations between blood Zinc concentrations and udder health in dairy cows. Rev. Méd. Vét., 164 (4), 183 - 190.

El-Gendy, M.E., Hafsa F.H. Youssef, E.O.H. Saifelnasr, Heba A. El-Sanafawy and Fatma E. Saba (2014). Relationship between udder characteristics and each of reproductive performance and milk production and milk composition in Zaraibi and Damascus dairy goats. Egyptian Journal of Sheep \& Goat Sciences. 9 (3): 95 - 104.

EL-Sabagh, M.R., M.A. Abd- Eldaim, DH. Mahboub and M. Abdel-Daim (2014). Effects of Spirulina Platensis algae on growth performance, antioxidative status and blood metabolites in fattening lambs. Journal of Agricultural Science. 6 (3): 92 - 98.

Gregorio, P.D., A.D. Trana, P. Celi, S. Claps and A. Rando (2014). Comparison of goat, sheep, cattle and water buffalo leptin $(L E P)$ genes and effects of the Intron 1 microsatellite polymorphism in goats. Animal Production Science. 54(9): 1285 -1262.

Hafez, A.A., E.I. Khalifa, H.R. Behery, Y.H. Mahrous, Amal A. Fayed and Hanan A. M. Hassanien (2015). Productive and reproductive performance of ewes and growth rate of lambs as affected by non-conventional energy supplement to rations. Egyptian Journal of Sheep \& Goat Sciences.10 (2): 81- 93.

Heidarpour, A., A. Fourouzandeh-Shahraki and S. Eghbalsaied (2011). Effects of Spirulina platensis on performance, digestibility and serum biochemical parameters of Holstein calves. African Journal of Agricultural Research. 6 (22): 5061- 5065.

Holman, B.W.B., A. Kashani and A.E.O. Malau-Aduli (2012). Growth and body conformation responses of genetically divergent Australian sheep to spirulina (Arthrospira platensis) Supplementation. American Journal of Experimental Agriculture. 2 (2): 160 -173.

Kalio, G.A., B.B. Okafor and J.N. Ingweye (2014). Haematology and biochemistry of West African Dwarf (wad) bucks fed crop by-products in humid tropical Nigeria. International Journal of science and technology. 18 (2): 1227-1234.

Khalifa, E.I., H.R. Behery, Y.H. Hafez, A.A. Mahrous, Amal A. Fayed and Hanan A. M. Hassanien (2013). Supplementing non-conventional energy sources to rations for improving production and reproduction performances of dairy Zaraibi nanny goats. Egyptian Journal of Sheep \& Goat Sciences. 8 (2): 69 - 83.

Khalifa, E.I., Hanan A.M. Hassanien, A.H. Mohamed and A.M. Hussein (2014). Effects of using yucca schidigera powder as feed additive on productive and reproductive efficiency of Zaraibi dairy goats. Egyptian Journal of Sheep \& Goat Sciences. 9 (2): 9 - 21.

Kulshreshtha, A., J. Zacharia and U. Jarouliya (2008). Spirulina in Health Care Management. Current Pharmaceutical Biotechnology. 9 (5): 400 - 405.

Kumar, D.D.K., V.K. Saxena and S.M.K. Naqvi (2015). The effect of nutritional stress on sperm motion characteristics and sexual behaviour of rams in a semi-arid tropical environment. Journal of Animal and Feed Sciences. 24 (2015): 107 - 112.

Kupras, L.P., I.S. Cekman and N.A. Gorcakova (2003). Spirulina Platensis ir sveikata. Ukrainos Medicinos mokslo akademija. Kijevas (in Ukrainian). pp. 86. 


\section{Khalifa et al.}

Liping, L., Q. Li-an, W. Yiquan and Y. Guorong (2011). Spirulina platensis extract supplementation attenuates oxidative stress in acute exhaustive exercise: A pilot study. International Journal of the Physical Sciences. 6(12): 2901 - 2906.

Mahboub, H.D.H., S.G.A. Ramadan, M.A.Y. Helal and Enas A.K. Aziz (2013). Effect of maternal feeding in late pregnancy on behaviour and performance of Egyptian goat and sheep and their offspring. Global Veterinaria. 11 (2): 168 - 176.

Mazokopakis, E.E., M.G. Papadomanolaki, A.A. Fousteris, D.A. Kotsiris, I.M. Lampadakis and E.S. Ganotakis (2014). The hepatoprotective and hypolipidemic effects of Spirulina (Arthrospira platensis) supplementation in a Cretan population with non-alcoholic fatty liver disease: a prospective pilot study. Annals of Gastroenterology. 27 (4): 387 - 394.

Meza-Herrera, C.A., J.M. Reyes-Avila, M. Tena-Sempere, F.G. Veliz-Deras, U. Macias-Cruz, R. Rodriguez-Martinez, and G. Arellano-Rodriguez (2014). Long-term beta-carotene supplementation positively affects serum triiodothyronine concentrations around puberty onset in female goats. Small Ruminant Research. 116 (2-3): 176 - 182.

NRC (2007). Nutrient Requirements of Small Ruminants: sheep, goats, cervids, and New World camelids. National Research Council of the National Academies, National Academies Press, Washington, D.C., U.S.A.

Panjaitan, T., S.P. Quigley, S.R. McLennan, A.J. Swain and D.P. Poppi (2014). Spirulina (Spirulina platensis) algae supplementation increases microbial protein production and feed intake and decreases retention time of digesta in the rumen of cattle. Animal Production Science. 9999 (9999): 1 - 10.

Panjaitan, T., S.P. Quigley, S.R. McLennan, A.J. Swain and D.P. Poppi (2015). Spirulina (Spirulina platensis) algae supplementation increases microbial protein production and feed intake and decreases retention time of digesta in the rumen of cattle. Animal Production Science. 55 (4): 535 - 543.

Parimi, N.S., M. Singh, J.R. Kastner, K.C. Das, L.S. Forsberg and P. Azadi (2015). Optimization of protein extraction from Spirulina platensis to generate a potential co-product and a biofuel feedstock with reduced nitrogen content. Frontiers in Energy Research. 3 (30): 1 - 9.

Ruitang, D. and T.J. Chow (2010). Hypolipidemic, antioxidant, and antiinflammatory activities of microalgae Spirulina. Cardiovasc. Therapeutics. 28: 33-45.

Rumosa-Gwaze, F., M. Chimonyo and K. Dzama (2012). Effect of season and age on blood minerals, liver enzyme levels, and faecal egg counts in Nguni goats of South Africa. Czech J. Anim. Sci., 5 (10): $443-453$.

Sadeghi, S., A. Rafat and M. Bohlouli (2014). Effect of crossbreeding on linear udder scores and their phenotypic relationships in Iranian FAT-Tailed ewe's. Biotechnology in Animal Husbandry. 30 (1): $61-77$.

Simkus, A., V. Oberauskas, J. Laugalis, R. Zelvyte, I. Monkevicience, A. Sederevicius, A. Simkiene, and K. Pauliukas (2007). The effect of weed Spirulina platensis on the milk production in cows. Veterinarija IR Zootechnika. Abstract, T. 38 (60).

SPSS (2013). Statistical package for social sciences, IBM ${ }^{\circledR}$ SPSS Statistics Data Editor 22 License Authorization Wizard, Chicago, USA.

Vacca, G.M., M. Pazzola, G. Piras, E. Pira, P. Paschino and M.L. Dettori (2014). The Effect of cold acidified milk replace on productive performance of suckling kids reared in an extensive farming system. Small Ruminant Research. 121 (2-3):161 - 167.

Vedi, M., S. Kalaiselvan, M. Rasool and E. Prince Sabina (2013). Protective effects of blue green algae spirulina fusiformis against galactosamine-induced hepatotoxicity in mice. Asian Journal Pharmceutical Clinical Research. 6 (3): 150 - 154.

Vishnu, N. and R. Sumathi (2014). Isolation of fresh water microalgae Chlorella sp and its antimicrobial activity on selected pathogens. International Journal of Advanced Research in Biological Sciences. Int. J.Adv. Res. Biol. Sci., 1 (3): 36 - 43.

Willems, O.W., S.P. Miller and B.J. Wood (2013). Assessment of residual body weight gain and residual intake and body weight gain as feed efficiency traits in the turkey (Meleagris gallopavo). Genetics Selection Evolution. 45 (26): 2 - 8. 
Yaakob, Z., E. Ali, A. Zainal, M. Mohamad and M.S. Takriff (2014). An overview: biomolecules from microalgae for animal feed and aquaculture. Journal of Biological Research. 21(6): 2 - 10.

Yener, N.A., O. Sinanoglu, E. Ilter, A. Celik, G. Sezgin, A. Midi, U. Deveci and F. Aksungar (2013). Effects of spirulina on cyclophosphamide-induced ovarian toxicity in rats: biochemical and histomorphometric evaluation of the ovary. Biochemistry Research International. 2013: 1 - 6.

\title{
تأثير اضافة مسحوق طحلب الأسبيرولينا على الأداء التناسلى والإنتاجى للماعز الزرايبى الحلاب
}

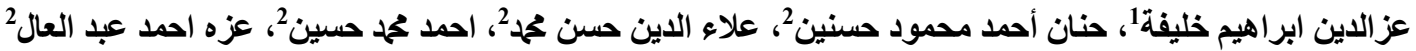 \\ 1معقد بحوث الإنتاج الحيوانس ، قسم بحوث الأغنام والماعز، مركز البحوث الزراعية،، الدقى، الجبزة، مصر

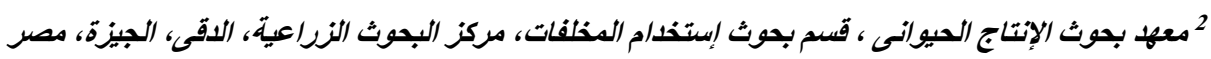

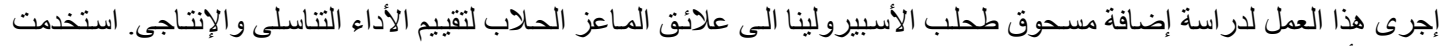

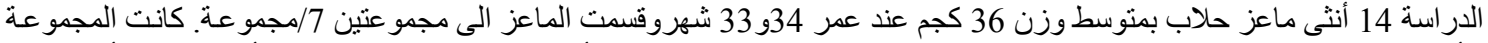

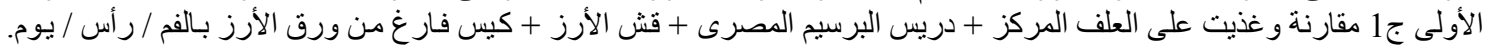

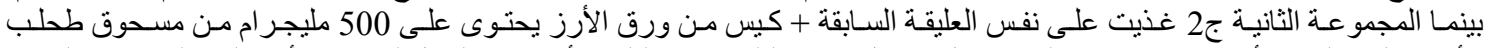

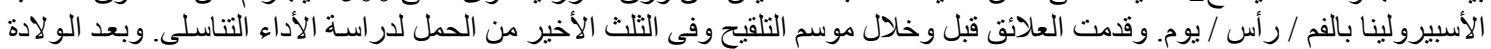

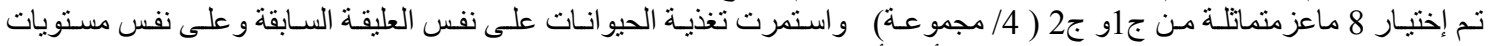

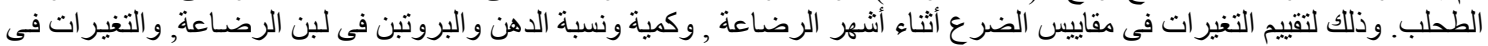

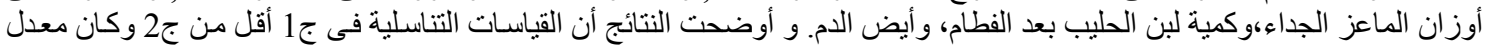

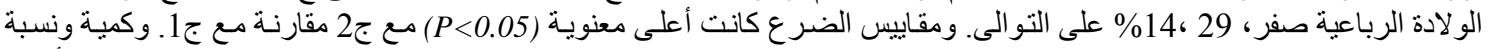

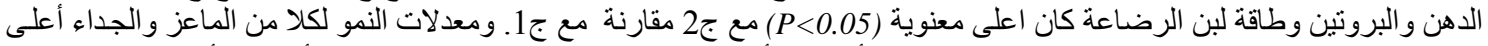

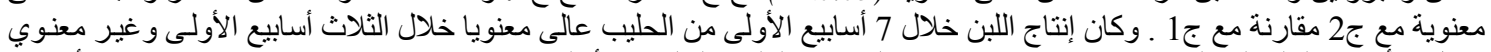

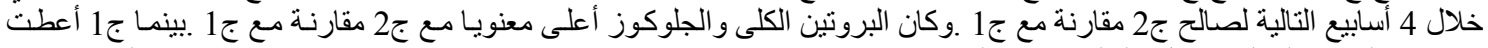

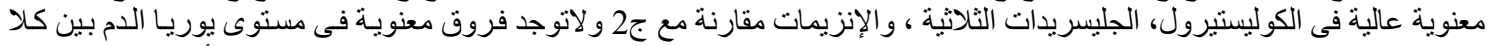

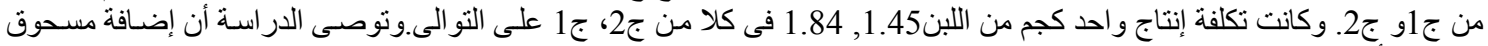
طحلب الأسبيرولينا هام لتغذية الماعز الحلاب وكمضاد للتاكسد ومنشط لجهاز المناعة و إنتاج اللبن و لا يقاو التام اجهزه الجسم.
\end{abstract}

